\title{
Opportunities and Challenges of Innovation and Entrepreneurship for College Students
}

\author{
Zhou Dong \\ Xijing University, Xi'an, Shaanxi, China, 710123
}

Keywords: innovation and entrepreneurship education; education mode; colleges and universities

\begin{abstract}
The 21st century is the rapid development of the Internet, and "Internet +" has gone into all walks of life in our country. The rapid development of "Internet +" has greatly promoted the rapid development of China's national economy, and provided many opportunities for the innovation and entrepreneurship of college students in China. The integration of "Internet + " and all walks of life also brings challenges to traditional business methods. This paper analyzes the problems and challenges encountered in innovation and entrepreneurship of college students, and proposes reasonable suggestions, in order to promote the enthusiasm and vitality of college students' innovation and entrepreneurship, and to improve their success rate, solve the problems in the employment of college students in China, and promote the economic and social development of our country.
\end{abstract}

\section{Introduction}

Innovation is the driving force of economic development. It has been widely used in our daily life such as the big data, Internet of things and cloud computing. So, the opportunities which created by the integration of the Internet and emerging industries provide a new direction for the rapid development of China's economy. For contemporary college students, it is possible to seize the present opportunity and provide direction for realizing the ideal of life in the "Internet + " era. The government work report of China in 2016 made clear that, China's policy will incline to new drivers, new industries and new formats of the "Internet $+"$ era. And under the pressure of employment and the Internet age, the government encourages college students to innovate and start their own businesses. Moreover, it provides a large number of preferential policies for college students' innovation and entrepreneurship. And those policies have stimulated the enthusiasm and vitality of college students' entrepreneurship. Although the government and colleges and universities has established many preferential policies to help college students to entrepreneurship, business is always both opportunities and challenges. So, college students' entrepreneurship must seize every policy to improve the success rate of entrepreneurship.

\section{The Opportunity of Innovation and Entrepreneurship of College Students}

\subsection{Strongly supports of college students' innovation and entrepreneurship}

From 1999 China begin to introduce innovative undertaking, China has formulated a series of policies to promote the self-employment of college students, but its effectiveness and the success rate of entrepreneurship are relatively low. However, this kind of result increases the psychological barrier for the innovation and entrepreneurship of college students. Early "entrepreneurship" is a kind of measure in order to alleviate employment pressure and the main social contradictions. The "mass entrepreneurship and innovation" proposed by premier li keqiang is an important driving force for China's economic transformation and sustainable development. At present, there are the biggest opportunities, such as the government support and the policy of innovation and entrepreneurship. The Chinese government from various aspects to develop and implement business lead plan of college students. And the government together with the universities create entrepreneurship foundation for providing the entrepreneurial guidance services, personnel, site, 
funds and other key measures. In this way, the government plans the overall resources of universities and colleges. And it will guide and encourage the innovation and entrepreneurship of college students. A series of government reports and policies are implemented which say the supports of the government for the college students' entrepreneurship. It can be said that the current policy is the most suitable for college students to start a business, and also it is the best time for college students to start a business. The college students who want to start a business must seize the opportunity which is strongly supports the innovation and entrepreneurship of college students by the government, and then light up their passion and realize their life value.

\section{2 "Internet +" provides a new model for college students' innovation and entrepreneurship}

Nowadays, there is no longer the era of traditional entrepreneurial management. The "Internet +" has become the main mode of entrepreneurship. Since 2015, innovation and entrepreneurship has formed the "Internet $+020+$ offline resources" startup mode under the impact of "Internet $+"$. The model is an entrepreneurial mode that connects various commercial channels with the Internet as a tool. The three-in-one entrepreneurial model has a highly innovative and highly profitable business operation mode. It provides a new platform for college students' innovation and entrepreneurship and greatly improves their success rate. Through the integration of new Internet technology and traditional entrepreneurial mode, a new mode of entrepreneurship adapted to this era is formed, which brings more opportunities for the innovation and entrepreneurship of college students.

\section{3 "Internet +" provides a new market for college students' innovation and entrepreneurship}

Internet technology is an important tool for the development of human intelligence, and it is a necessary tool for social and economic development. It is also an important direction for the development of the country. Only by cultivating innovative thinking can we keep the momentum of the country forward, and we can prepare the entrepreneurial resources based on the market demand. The business model of "Internet + " era is a combination of online and offline, which greatly expands the field of traditional market entrepreneurship and creates a large number of consumer markets. According to the "broadband status report" issued by The United Nations at the end of 2016, there are 3.5 billion global Internet in the world and 721 million people in China. So, China has become the largest Internet market. Through the Internet, shopping, takeout, entertainment and other consumption account for about $20 \%$ of the total consumption. Thus, the "Internet $+"$ era has provided a large number of new market for entrepreneurship. It can be said that there are still a lot of needs and deep integration with traditional industries in China's entrepreneurial market. We need to seize the opportunity of entrepreneurship in emerging markets.

\section{Challenges Faced by College Students in Innovation and Entrepreneurship}

\subsection{Less entrepreneurial experience and social resources}

At present, the main reasons that hinder the success of college students' innovation and entrepreneurship are the following two reasons: the lack of entrepreneurial experience and the lack of social resources. Experience is one of the main business failure problem, mainly because the college students in the early stage of the business for innovation entrepreneurship cruel and risk awareness is not enough. Because they do not have good psychological preparation, they cannot cope with the complex and changeable characteristics of the market, which leads to the inaccuracy of their work and service orientation. It is because there are no clear target market and the lack of risk consciousness, as a result, it does not have sufficient investigation and research on market scale, marketing mode and product price in the process of entrepreneurship. Although the government and universities support college students' entrepreneurship, their share of social resources is still very low. This situation will lead to the failure to get effective help in the face of difficulties and setbacks, which can easily lead to frustration. College simply through the way of education to enhance their knowledge of entrepreneurship, and through a variety of innovative entrepreneur contest to increase its entrepreneurial experience, but cannot provide sufficient resources for 
business practice. Because innovation and entrepreneurship incubation base is not sound, which lead entrepreneurial students to have no corresponding management and management experience, and then ultimately leads to failure.

\subsection{Imperfect government policies}

Although the Chinese government released a series of measures to promote college students' entrepreneurial innovation, but these policies have not formed a complete system to help college students entrepreneurship, which still exist many problems. For example, there is no concrete implementation plan in the policy, which makes it difficult to implement. And part of the preferential policy is not suitable for graduate students, when they qualify for business qualification, maybe the policy has been cancelled, this kind of situation will lead to the government's preferential policies are difficult to really help students who want to venture. Loans and financing, offices, tax breaks and other preferential is not necessarily at the begin. So, the students who want to start their own business will not xperience the government's preferential measures, and eventually they will fail because of social pressure.

\section{Build the Main Body of Practice Platform Pluralism}

In the era of "Internet +", entrepreneurial activity is no longer need fixed venues, fixed time. Which lays the foundation for the construction of diversified practice platform, and it also broadens the path of entrepreneurial practice while reducing the cost of start-up practice. First, the government has timely issued policies to encourage and support the innovation and entrepreneurship of college students, rather than just the call and empty policy guidance policies. Second, government departments should update the information of industrial layout adjustment, economic structure transformation and industrial development demand in a timely manner, so as to enable students with entrepreneurial requirements to grasp the orientation and market space of entrepreneurship. Third, the government needs to give relatively sufficient start-up capital support to college students, and gradually establish a complete system of start-up capital acquisition and repayment.

In the process of building a platform for entrepreneurship, We should not only establish a more smooth and effective cooperation mechanism, but also actively try to provide tracking and guidance services for college students to provide technical, management and financial services anytime and anywhere.

\section{Conclusion}

The era of "Internet + " is a time full of opportunities and challenges. College students have advantaged superiority as a new force, but also have a very broad prospect. In the process of innovation and entrepreneurship, opportunities and challenges coexist, and college students will face numerous problems and challenges. Government and colleges must work together to encourage and guide more students for entrepreneurship, promote the development of China's innovation entrepreneurship and success ratio, help students achieve their goals in life, and promote social harmony and stability.

\section{References}

[1] Bulgacov Y L M, de Camargo D, de Meza M L F G, et al. Conditions for female and young Brazilian entrepreneurs: Common aspects for guiding public policies for innovative ventures. African Journal of Business Management (2014), p. 89-100

[2] Muzychenko O. Cross-cultural entrepreneurial competence inbusiness o,p.ortunities. European Management Journal (2008), p. 366-377

[3] Nicos Nicolaou et al. Is the Tendency to Engage in Entrepreneurship Genetic? Management 
Science (2008), p. 167-179

[4] Georgvon Graevenitz, Dietmar Harhoff, Richard Weber. The erects of entrepreneurship education. Journal of Economic Behavior \& Organization (2010), p. 90-112

[5] Agbim KC, Ayatse FA, Oriarewo GO. Entrepreneurial learning: a social and experiential method of entrepreneurship development among indigenous female entrepreneurs in Anambra State, Nigeria. International Journal of Scientific and Research Publications (2013), p. 50-53

[6] James G March. Exploration and exploitation in organizational learning. Organization Sciences (1991), p. 71-87

[7] Lewin, A.Y and Carrool, T. N. The Coevolution of New Organization Forms. Organization Science (2003), p. 53-55

[8] A. Y Chong, K.B.Ooi, A.Sohal .The Relationship between Supply Chain Factors and Adoptio of e-Collaboration Tools: An Empirical Examination. International Journal of Production Economics (2009), p. 7-11 